\title{
Production of Structural OSB with Cajueiro (Anacardium sp.) and Amescla (Trattinikia sp.) - A Preliminary Study
}

\author{
Jonathan Francisco de Freitass ${ }^{1}$, Amós Magalhães de Souza ${ }^{1}$, Luiz Antônio Melgaço Nunes Granco ${ }^{2}$, \\ Eduardo Chahud ${ }^{3}$, André Luis Christoforo ${ }^{4, *}$, Francisco Antonio Rocco Lahr ${ }^{5}$
}

\begin{abstract}
${ }^{1}$ Wood and Timber Structures Laboratory (LaMEM), São Carlos Engineering School, São Paulo University (USP), São Carlos - SP, Brazil ${ }^{2}$ Faculty of Engineering and Architecture, FUMEC University, Belo Horizonte - MG, Brazil

${ }^{3}$ Department of Civil Engineering, Federal University of Minas Gerais (UFMG), Belo Horizonte - MG, Brazil

${ }^{4}$ Centre for Innovation and Technology in Composites - CITeC, Department of Civil Engineering (DECiv), Federal University of São Carlos, São Carlos - SP, Brazil

${ }^{5}$ Department of Structural Engineering (SET), Engineering School of São Carlos (EESC), São Paulo University (USP), São Carlos - SP, Brazil
\end{abstract}

\begin{abstract}
The purpose of this research is to demonstrate, in an original study, the potentiality of the use of Cajueiro (Anacardium sp.) and Amescla (Trattinikia sp.), two low density tropical wood species, for producing OSB (Oriented strand boards), structural panels that replace plywood for several building purposes. In those panels, wood strands can be disposed in a specific direction or in random distribution, in order to reach the desirable mechanical properties. In this case, the strands were oriented by a separator to generate layers in mass proportion 20:60:20 (outer, inner and outer layers). Then these pre-panels went to a pre-pressing to form the mattress. Finally, they were pressed at $100^{\circ} \mathrm{C}$, by 10 minutes, under 4.5 MPa pressure, using castor oil based bicomponent polyurethane resin as adhesive. They were produced eight panels (four with Cajueiro e four with Amescla), with nominal dimensions $350 \mathrm{~mm}$ length, $350 \mathrm{~mm}$ width and $10 \mathrm{~mm}$ thickness. Results showed that these wood species can be used to produce OSB, mainly considering values obtained in mechanical tests, that are superior to OSB produced in Brazilian enterprises and can be classified as OSB/4, as recommended by European standard EN 300. Research should continue to be developed in order to reach more adequate performance in swelling and water absorption.
\end{abstract}

Keywords Oriented strand board (OSB), Cajueiro, Amescla, Alternative tropical wood species

\section{Introduction}

Utilization wood based products is increasing is all world, in spite of wood species are characterized by large differences in terms of chemical composition and anatomical constitution. These differences can cause defects, that's why in several cases solid wood application can be limited. Some wood based products, as OSB (Oriented strand board), present interesting properties for structural purposes, as substitute of plywood in framework and composite beams [1-4].

Wood panels are made from plies or particles in different dimensions, glued all together by the use of resin, pressure and heat [5]. Wood panels are usually applied in furniture, building constructions (such doors, floors, sidings, among others) and package. In Brazil, the first enterprise to produce OSB was MASISA Inc, in 2002, nowadays it produces

* Corresponding author:

alchristoforo@gmail.com (André Luis Christoforo)

Published online at http://journal.sapub.org/ijme

Copyright (C) 2017 Scientific \& Academic Publishing. All Rights Reserved
$350,000 \mathrm{~m}^{3}$ per year [6]. For OSB production, industries can use wood of low quality and faster growing with no restriction for diameter and length of the logs.

In agreement with European standard EN 300 [7], OSB is a panel with several layers composed by wood strands that can be glued with different kind of adhesives $[1,2,4]$. In OSB, the wood strands can be disposed in a specific direction or in random distribution, in order to reach the desirable mechanical properties. In these circumstances, OSB panels can be used in building construction in applications previously cited.

The both wood species Cajueiro (Anacardium sp.) and Amescla (Trattinikia sp.) are typical from center-west from Brazil (States of Mato Grosso and Tocantins). These are medium density woods, similar to those from Pinus genus, the most commonly utilized for panel production. In that region of Brazil, wood industries usually employ these species in very small structures, furniture and package. Hence, the purpose of this paper is to demonstrate, in an original preliminary study (the first one referred to Cajueiro and Amescla for wood based products) their potentiality for structural OSB production. 


\section{Material and Methods}

For OSB production, in laboratorial scale, Cajueiro and Amescla strands were used. It has been followed the instruction set proposed by [8], among others. At beginning, wood battens were cut in small pieces with $90 \mathrm{~mm}$ width and $45 \mathrm{~mm}$ thickness. All these pieces were processed in a strand generator in order to obtain the strands. Around $20 \mathrm{~kg}$ of strands from each wood species were obtained.

Later, the strands were mixed together with castor oil base bicomponent polyurethane resin, once it had already showed high performance in increasing mechanical properties as is showed by [1], [6] and [8]. Each panel weigh around $1 \mathrm{~kg}$ (density about $0,8 \mathrm{~g} / \mathrm{cm}^{3}$, equivalent to the commercial boards).

Firstly, strands were oriented by a separator in order to form layers in the mass proportion of 20:60:20, shaping the panel. Then these pre-panels went to a pre-pressing to form the mattress. Finally, they were pressed at $100^{\circ} \mathrm{C}$, by 10 minutes $[9,10]$, under $4.5 \mathrm{MPa}$ pressure.

They were produced eight panels (four with Cajueiro e four with Amescla), with nominal dimensions $350 \mathrm{~mm}$ length, $350 \mathrm{~mm}$ width and $10 \mathrm{~mm}$ thickness. After the panel production, they spent 48 hours in a seasoned room, with the aim of let the resin curate.

From these panels, specimens were cut to be tested in order to determine some physical mechanical and physical properties, following the European standard EN 300 [7] prescriptions. Table 1 shows the dimensions and the number of specimens for each test (by panel).

Table 1. Tests made with OSB panels

\begin{tabular}{ccccc}
\hline Test & Initials & Width & Length & Sp \\
\hline Bending Static & BS & $50 \mathrm{~mm}$ & $250 \mathrm{~mm}$ & 4 \\
Tension Parallel to Face & TP & $50 \mathrm{~mm}$ & $50 \mathrm{~mm}$ & 4 \\
Screw Pull Out (Surface) & PSS & $75 \mathrm{~mm}$ & $150 \mathrm{~mm}$ & 1 \\
Screw Pull Out (Top) & PST & $65 \mathrm{~mm}$ & $115 \mathrm{~mm}$ & 1 \\
Density & D & $50 \mathrm{~mm}$ & $50 \mathrm{~mm}$ & 4 \\
Thickness Swelling & S & $50 \mathrm{~mm}$ & $50 \mathrm{~mm}$ & 4 \\
Water Absorption & A & $50 \mathrm{~mm}$ & $50 \mathrm{~mm}$ & 4 \\
\hline
\end{tabular}

- Sp: number of specimen by panel produced.

All tests were carried out according the methodology of EN 300 [7] and its correlated documents. They were performed in Wood and Timber Structures Laboratory (LaMEM), Structural Engineering Department, São Carlos Engineering School, University of São Paulo; and in Civil Engineering Department, Federal University of Minas Gerais (UFMG).

\subsection{Physical and Mechanical Properties}

Density of the samples was obtained using Equation 1.

$$
D=\frac{M}{V}
$$

In Equation 1, M is the mass and $\mathrm{V}$ the volume of the specimens.

Thickness swelling (S) and water absorption (A) were determined (for 2 and 24h) in percentage, using Equations 2 and 3 , respectively.

$$
\begin{aligned}
& S=\frac{E_{2}-E_{1}}{E_{1}} \cdot 100 \\
& A=\frac{M_{2}-M_{1}}{M_{1}} \cdot 100
\end{aligned}
$$

From Equations 2 and 3, $E_{2}$ is the specimen thickness after water immersion; $E_{1}$ is the thickness before the immersion, $\mathrm{M}_{2}$ is the mass of the specimen after water immersion and $\mathrm{M}_{1}$ is the mass before the water immersion.

The parameters obtained in the mechanical tests were the bending stiffness (Modulus of elasticity - MOE) and bending strength (Modulus of rupture - MOR), both in MPa. These variables were calculated by Equations 4 and 5 .

$$
\begin{gathered}
M O E=\frac{\left(F_{2}-F_{1}\right) \cdot L^{3}}{4 \cdot b \cdot t^{3} \cdot\left(a_{2}-a_{1}\right)} \\
M O R=\frac{3 \cdot F_{\max } \cdot L}{2 \cdot b \cdot t^{2}}
\end{gathered}
$$

From Equation 4 and $5, \mathrm{~L}$ is the specimen span $(\mathrm{mm}), \mathrm{F}_{2}$ corresponds to $50 \%$ of the estimated maximum force $\left(\mathrm{F}_{\max }\right)$, $\mathrm{F}_{1}$ corresponds to $10 \%$ of $\mathrm{F}_{\max }(\mathrm{N}), \mathrm{a}_{2}-\mathrm{a}_{1}$ are the displacements at $50 \%$ and $10 \%$ of $\mathrm{F}_{\max }(\mathrm{m}), \mathrm{b}$ is the width $(\mathrm{mm})$ and $\mathrm{t}$ is the thickness $(\mathrm{mm})$ of specimen.

For tension parallel to face, the calculations was made by Equation 6 , where $\mathrm{a}$ and $\mathrm{b}$ are the specimens widths in both directions.

$$
T P=\frac{F_{\max }}{a \cdot b}
$$

Finally, for the both tests of screw pull out (surface and top), force is given in N. All mechanical tests were carried out in a Universal Machine Amsler (250 kN load capacity).

\section{Results and Discussion}

\subsection{Physical Tests}

Table 2 shows the values for density for the panels OSB manufactured with Cajueiro and Amescla wood species, where $\mathrm{SD}$ is the standard deviation and $\mathrm{CV}$ is the coefficient of variation.

Table 2. Values of Density for OSB

\begin{tabular}{cc|cc}
\hline Cajueiro & $\mathbf{D}\left(\mathbf{k g} / \mathbf{m}^{\mathbf{3}}\right)$ & Amescla & $\mathbf{D ~}\left(\mathbf{k g} / \mathbf{m}^{\mathbf{3}}\right)$ \\
\hline Average & 814 & Average & 805 \\
SD & 90 & SD & 114 \\
CV (\%) & 11 & CV (\%) & 14 \\
\hline
\end{tabular}

We can see that the OSB panels from Cajueiro and Amescla presented analogue density. Both values are 
slightly higher than those found by [1], $742 \mathrm{~kg} / \mathrm{m}^{3}$, for OSB produced with Pinus sp.

As it could be expected, for both OSB is possible to observe a significant increase in thickness swelling and water absorption, from $2 \mathrm{~h}$ to $24 \mathrm{~h}$ of water submersion.

Tables 3 and 4 shows the values of swelling and absorption for the panels OSB manufactured with Cajueiro and Amescla wood species, respectively.

Table 3. Swelling and Absorption for Cajueiro

\begin{tabular}{ccccc}
\hline Cajueiro & S-2h (\%) & S-24h(5) & A-2h (\%) & A-24h (\%) \\
\hline Average & 10 & 19 & 12 & 31 \\
SD & 4 & 6 & 5 & 6 \\
CV (\%) & 40 & 32 & 42 & 20 \\
\hline
\end{tabular}

Table 4. Swelling and Absorption for Amescla

\begin{tabular}{ccccc}
\hline Amescla & S-2h (\%) & S-24h(5) & A-2h (\%) & A-24h (\%) \\
\hline Average & 13 & 24 & 16 & 40 \\
SD & 6 & 8 & 7 & 12 \\
CV (\%) & 46 & 33 & 46 & 30 \\
\hline
\end{tabular}

The values of thickness swelling and water absorption of OSB panels with Cajueiro are smaller than those with Amescla. It can be explained because Cajueiro presents high extractives quantity than Amescla, as pointed by [11].

These values permit to classify OSB with Cajueiro and Amescla strand as OSB/2, based on EN 300 (2006). OSB/1 is the type recommended to application in "load-bearing boards for use in dry conditions".

\subsection{Mechanical Tests}

The mechanical tests (static bending and tension parallel to face) were performed as described earlier. Calculations were elaborated using Equations 4, 5 and 6 to obtain the MOE, MOR and tensile strength parallel to the face (TP), respectively. Tables 5 and 6 presents the results of these properties for the Cajueiro and Amescla wood species.

Table 5. Values of MOE, MOR and TP for OSB from Cajueiro

\begin{tabular}{cccc}
\hline Cajueiro & MOE (MPa) & MOR (MPa) & TP (MPa) \\
\hline Average & 8933 & 48 & 5 \\
SD & 4290 & 9 & 2 \\
CV $(\%)$ & 48 & 19 & 40 \\
\hline
\end{tabular}

Table 6. Values of MOE, MOR and TP for OSB from Amescla

\begin{tabular}{cccc}
\hline Amescla & MOE (MPa) & MOR (MPa) & TP (MPa) \\
\hline Average & 7576 & 39 & 4 \\
SD & 1169 & 9 & 1 \\
CV (\%) & 15 & 23 & 25 \\
\hline
\end{tabular}

It can be observed that the values of Cajueiro OSB panels were higher than the values found for OSB panels of the Amescla. The MOE values were close to the value found by [1] which was $8679 \mathrm{MPa}$ for OSB panels of Pinus sp.
But the MOR value found by [1] was $60 \mathrm{MPa}$ higher than the Cajueiro $48 \mathrm{MPa}$ and $39 \mathrm{MPa}$ for Amescla. But, in this research, TP values of $5 \mathrm{MPa}$ and $4 \mathrm{MPa}$ were higher than found for the OSB with Pinus sp. (2 MPa). It can be justified because Shizolobium amazonicum presents very small extractives quantity, aspect that makes viable the high performance of the resin employed.

These values permit to classify OSB with Cajueiro and Amescla strand as OSB/4, based on EN 300 [7]. OSB/4 is the type recommended to application in "heavy duty load-bearing boards for use in humid conditions", the higher one of the mentioned standard.

Tables 7 and 8 presents the results of screw pull out surface [PSS] and screw pull out top [PST].

Table 7. PSS and PST values for OSB Cajueiro

\begin{tabular}{ccc}
\hline Cajueiro & PSS (N) & PST (N) \\
\hline Average & 521 & 415 \\
SD & 74 & 194 \\
CV $(\%)$ & 14 & 47 \\
\hline
\end{tabular}

Table 8. PSS and PST values for OSB Amescla

\begin{tabular}{ccc}
\hline Amescla & PSS (N) & PST (N) \\
\hline Average & 432 & 265 \\
SD & 88 & 95 \\
CV $(\%)$ & 20 & 36 \\
\hline
\end{tabular}

Screw pull out mean values were greater for OSB panels with Cajueiro compared with Amescla panels. Both of them were lower than the values found by [1] which was approximately $1500 \mathrm{~N}$ for OSB panels of Pinus sp. It was not possible identify physical reasons for these differences.

\section{Conclusions}

Even considering the pioneering character of this first study involving the tropical wood species (Cajueiro and Amescla), it's possible to conclude that both of them are viable for employing in OSB manufacturing, in laboratorial scale. Results show a very interesting mechanical performance of the panels, with a consequent possibility of classify them as OSB4, based on correspondent requirements of EN 300 [7].

Obviously, the research must be developed in order to reach more adequate performance in swelling and water absorption.

\section{ACKNOWLEDGMENTS}

By all support provided, the authors are grateful to Higher Education Improvement Coordination (CAPES); National Council for Scientific and Technological Development (CNPq); and to the four Universities involved. 


\section{REFERENCES}

[1] Ferro, F. S.; Almeida, T. H.; Almeida, D. H.; Christoforo, A. L.; Rocco Lahr, F. A. Physical Properties of OSB Panels Manufactured with CCA and CCB Treated Schizolobium amazonicum and Bonded with Castor Oil Based Polyurethane Resin. International Journal of Materials Engineering, v. 6, p. 151-154, 2016.

[2] Souza, A. M.; Varanda, L. D.; Christoforo, A. L.; Nascimento, M. F.; Poleto, S. F. S.; Panzera, T. H.; Rocco, F. A. L. Modulus of Elasticity in Static Bending for Oriented Strand Board (OSB). International Journal of Composite Materials, v. 4, p. 56-62, 2014.

[3] Iwakiri, S. et al (2005). Produção de painéis aglomerados de alta densificação com uso de resina

melamina-uréia-formaldeído. Cerne. V. 11, n 4, p. 323-328, out/dez. 2005.

[4] Bertolini, M. S.; Christoforo, A. L.; Lahr, F. A. R. Thermal insulation particleboards made with wastes from wood and tire rubber. Key Engineering Materials, v. 668, p. 263-269, 2016.

[5] Freitas, J. F. Estudo Preliminar sobre A Utilização da Cana-de-açúcar e seus Derivados para Produção de Hardboards. 113f. Dissertação (Mestrado em Ciências e Engenharia dos Materiais) Escola de Engenharia de São Carlos, Universidade de São Paulo, São Carlos, 2015.
[6] Magalhães, S., A.; Varanda, L. D.; Macedo, B. L.; Almeida, D. H; Bertolini, M. S.; Christoforo, A. L.; Lahr, F. A. R. Mechanical Properties of OSB Wood Composites with Resin Derived from a Renewable Natural Resource. International Journal of Composite Materials (Online), v. 4, p. 157-161, 2014.

[7] European Committee for Standardization - EN 300. Oriented Strand Boards (OSB) - Definitions, classification and specifications, Portugal, 2006.

[8] Iwakiri, S. Mendes, L. M. Saldanha, L. K. (2002). Produção de chapas de partículas orientadas "OSB" de Eucalyptus grandis com diferentes teores de resina, parafina e composição em camadas. Ciência Florestal, Santa Maria, v. 13 , n. 1, p. 89-94.

[9] Ferro, F. S.; Icimoto, F. H.; Souza, A. M.; Almeida, D. H.; Christoforo, A. L.; Rocco Lahr, F. A. Produção de painéis de partículas orientadas (OSB) com Schizolobium amazonicum e resina poliuretana à base de óleo de mamona. Scientia Forestalis (IPEF), v. 43, p. 313-320, 2015.

[10] Bertolini, M. S.; Christoforo, A. L.; Calil Neto, C.; Rocco Lahr, F. A. Particulate Composites with Wastes from Treated Wood and Tire Rubber. Advanced Materials Research (Online), v. 1025-1026, p. 288-291, 2014.

[11] Instituto Brasileiro do Meio Ambiente e dos Recursos Naturais Renováveis. Madeiras da Amazônia. Coord. Márcia Helena Bezerra Marques et al., 141p., 1997. 